Research Article

\title{
Effect of the Third Element Ni on the Solidification Microstructure of Undercooled Cu-40 wt.\% Pb Monotectic Alloy Melt
}

\author{
Xi Hao $\mathbb{D}^{1,2}$ Yugui Li $\mathbb{D},{ }^{1,2,3}$ Ying $\mathrm{Hu},{ }^{1,2}$ and Guihong Geng $\mathbb{D}^{4}$ \\ ${ }^{1}$ The Coordinative Innovation Center of Taiyuan Heavy Machinery Equipment, Taiyuan University of Science and Technology, \\ Taiyuan 030024, China \\ ${ }^{2}$ Shanxi Provincial Key Laboratory of Metallurgical Equipment Design and Technology, \\ Taiyuan University of Science and Technology, Taiyuan 030024, China \\ ${ }^{3}$ School of Materials Science and Engineering, Taiyuan University of Science and Technology, Taiyuan 030024, China \\ ${ }^{4}$ School of Materials Science and Engineering, North Minzu University, Yinchuan 750000, China
}

Correspondence should be addressed to Yugui Li; liyugui2008@163.com

Received 4 August 2019; Accepted 17 September 2019; Published 24 October 2019

Guest Editor: Dinh Gia Ninh

Copyright $\odot 2019 \mathrm{Xi}$ Hao et al. This is an open access article distributed under the Creative Commons Attribution License, which permits unrestricted use, distribution, and reproduction in any medium, provided the original work is properly cited.

In this paper, the evolution of solidification microstructure of $\mathrm{Cu}-40 \mathrm{wt} . \% \mathrm{~Pb}$ monotectic alloy of the third element Ni pair under deep undercooling conditions was studied. By comparing the phenomena of liquid phase separation during deep undercooling and rapid solidification of $\mathrm{Cu}-40 \mathrm{wt} . \% \mathrm{~Pb}$ monotectic alloy, the melt of the alloy increases with the undercooling, and the solidification structure appears uneven or even stratified. With the addition of the third element $\mathrm{Ni}$, the liquid phase separation can be effectively inhibited by the change of interfacial energy. The solidified structure undergoes the transformation from coarse dendrite to the first kind of granular and refined dendrite in a wide undercooling range. When the undercooling reaches $143 \mathrm{~K}$, the structure begins to show an inhomogeneous trend.

\section{Introduction}

$\mathrm{Cu}-\mathrm{Pb}$ monotectic alloys have broad application prospects because of their excellent properties such as strong impact resistance, high fatigue strength, and high thermal conductivity. They have been widely used in many fields. Due to their excellent wear resistance, they have been widely used in self-lubricating antifriction materials [1-3]. From the thermodynamic point of view, the solidification process of the $\mathrm{Cu}-\mathrm{Pb}$ monotectic alloy is two-phase separation. Under the conventional solidification conditions, it is decomposed into two liquid phases with different compositions. Because of the density difference between the two liquid phases, segregation is easy to occur. Even more, there will be a phenomenon of component stratification $[4,5]$, which makes it difficult to directly prepare homogeneous monotectic alloy materials by conventional solidification methods, thereby limiting the application of monotectic alloys in industrial fields.

In order to obtain a solidified structure of a monotectic alloy having a uniform dispersed phase structure, a preparation method for homogenizing a plurality of monotectic alloys has been studied [6,7], A liquid phase preparation technique that has been successful both in theory and in practice has not yet been found. The quenching rapid solidification technique in many preparation techniques [8], although only suitable for the preparation of low-dimensional homogeneous monotectic alloys, gives us an inspiration: if the solidification of the bulk alloy melt passes through the liquid phase immiscible zone as soon as possible, when the second phase does not have enough time to complete the dynamic process of liquid phase separation, a monotectic alloy in which the second phase is uniformly distributed to the matrix can be obtained (Figure 1). In 


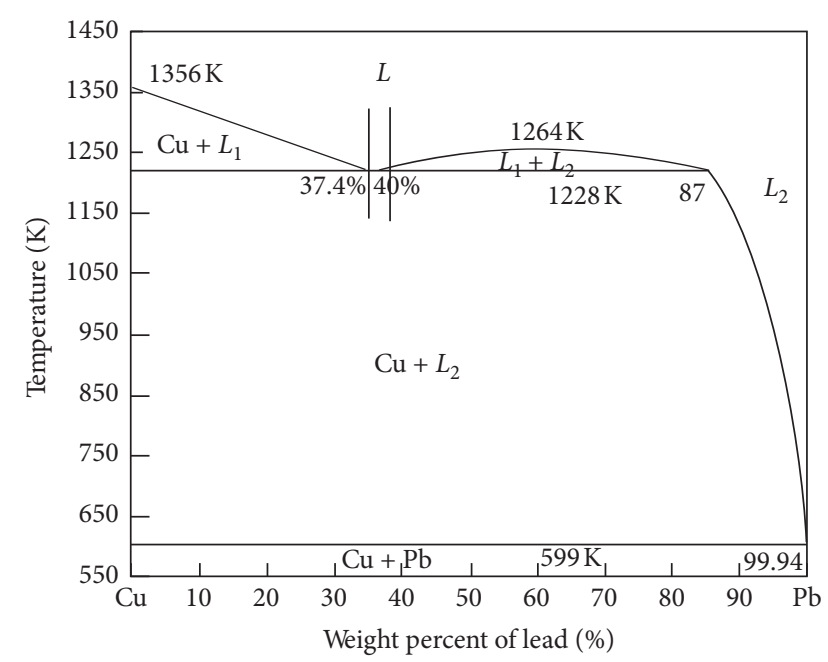

FIgURE 1: Immiscible alloy equilibrium phase diagram: $\mathrm{Cu}-\mathrm{Pb}$ monotectic alloy.

addition, it is also an effective method to add the third component to change the solidification structure of the alloy [9-12]. In this paper, the deep undercooling method was used to add the third component Ni to the overperformed $\mathrm{Cu}-40$ wt.\% $\mathrm{Pb}$ monotectic alloy. The third element is the solidification structure and solidification behavior of the alloy of the component.

\section{Experimental}

The experimental material is $\mathrm{Cu}-40 \mathrm{wt} . \% \mathrm{~Pb}$ monotectic alloy. The sample weighs about $15 \mathrm{~g}$. The crucible is made of pure quartz with $99.99 \%$ purity of electrolytic pure $\mathrm{Cu}$ and $99.75 \% \mathrm{~Pb}, 99.9 \%$ purity of the third element of $\mathrm{Ni}$, and $5 \%$ addition of total mass. The experimental method of deep undercooling is purification of molten glass and cyclic superheating. Deep undercooling experiment was carried out on GP30W-G7, a high-frequency induction heating device. The output power of the high-frequency generator is $30 \mathrm{~kW}$, and the working frequency is $300-50 \mathrm{KHz}$. The specific experimental process is as follows: firstly, about $2 / 3$ of the weight of glass purifier and $\mathrm{Cu}$ are added to the quartz crucible, and then after the complete melting of copper, lead, $\mathrm{Ni}$, and the remaining glass purifier are added in turn; secondly, under the protection of molten glass, the alloys with the above components are melted in situ, and the alloys are superheated cyclically. The superheated temperature is $1500 \mathrm{~K}$, and the superheated time is 5 minutes. When the air bubbles are completely eliminated, the power supply is cut off to make the sample cool naturally. A CIT-2M K $\mathrm{K}_{2 \mathrm{H}}$ infrared thermometer is used in the heating and cooling process. Its temperature range is $623 \mathrm{~K}-2323 \mathrm{~K}$ and response time is $1 \mathrm{~ms}$. The glass purifier is $\mathrm{B}_{2} \mathrm{O}_{3}$ and $\mathrm{Na}-\mathrm{Ca}-\mathrm{Si}$ glass, and the addition amount is $20 \%$ of the sample weight. Metallographic specimens were intercepted on fully solidified specimens. Microstructure and composition of the samples were analyzed by SS-550 Shimadzu scanning electron microscopy, a PHoenix EDAX-2000 energy dispersive spectrometer, and X-ray diffraction (6000X). The schematic diagram of the specific test device is shown in Figure 2.

\section{Results and Discussion}

3.1. Solidification Behavior of Cu-40 wt.\% Pb Monotectic Alloy and $\mathrm{Cu}-40 w t . \% \mathrm{~Pb}-5 \mathrm{wt} . \% \mathrm{Ni}$. The schematic diagram of melt cooling curve of hypermonotectic $\mathrm{Cu}-40 \mathrm{wt} . \% \mathrm{~Pb}$ alloy is shown in Figure 3 [13]. $T_{\mathrm{L}}$ is the liquidus temperature of $\mathrm{Cu}-\mathrm{Pb}$ alloy and $T_{N}$ is the monotectic reaction temperature of $\mathrm{Cu}-\mathrm{Pb}$ alloy. As can be seen from the figure, when the melt temperature of the alloy is lower than the equilibrium liquidus temperature and falls to $T$, the first inflection point appears on the cooling curve, and then the temperature rises back to $T_{r}^{\prime}$, that is, the first reglow occurs, and then the temperature decreases. When the temperature falls to $T_{n}$, the second inflection point appears on the cooling curve, and then the temperature rises back to $T_{r}$ and the second reglow occurs, and then no reglow occurs. The alloy system enters the natural solidification stage until it is cooled to room temperature, and the solidification process of the sample is completed. During the whole solidification process, the alloy melt reglow twice, and the liquid phase separation of the alloy must occur during the cooling process.

The cooling curve diagram of the melt solidification process of undercooled $\mathrm{Cu}-40$ wt.\% $\mathrm{Pb}-5 \mathrm{wt} . \% \mathrm{Ni}$ alloy shown in Figure 4 shows that the dotted line in Figure 4 is a monotectic reaction line. The solidification process can be divided into three stages:

(i) In Figure 4(a), only one reglow was detected, so it can be inferred that no liquid phase separation occurred at low undercooling. At deep undercooling, there is a slight reglow process on the cooling curve due to liquid nucleation, as shown in Figure 4(b), which is the phase of liquid phase separation before melt solidification, that is, $T_{n}^{\prime} \longrightarrow T_{r}^{\prime}$ stage in Figure 4 .

(ii) Once solid phase nucleation occurs in the melt, the crystals grow rapidly to the undercooled melt at a very fast speed. The free-growing solid phase crystals can instantly grow over the whole sample, which results in the obvious reglow phenomenon of the melt. Therefore, this stage is the rapid solidification stage in the initial stage of the melt, that is, $T_{n} \longrightarrow T_{r}$ stage in Figure 4 .

(iii) After re-glow, the alloy system enters a slow solidification stage with natural cooling at furnace temperature.

It can be seen that the solidification behavior of $\mathrm{Cu}$ 40 wt.\% monotectic $\mathrm{Pb}$ alloy is changed within a certain undercooling range after the addition of the third element $\mathrm{Ni}$.

3.2. Comparison of Solidified Microstructures of Cu- 40 wt.\% $\mathrm{Pb}$ Monotectic Alloy and Cu-40wt.\% $\mathrm{Pb}-5 w \mathrm{w} . \% \quad \mathrm{Ni}$. Figure 5 shows the solidification structure of $\mathrm{Cu}-40$ wt. $\% \mathrm{~Pb}$ monotectic alloy at different degrees of undercooling. In the 


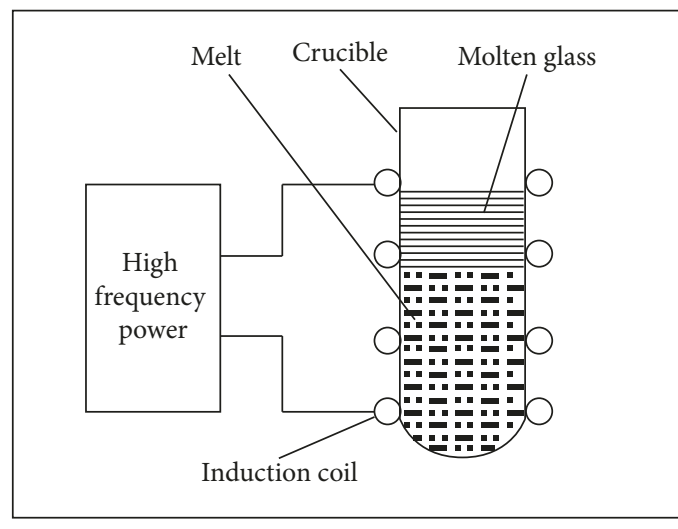

(a)

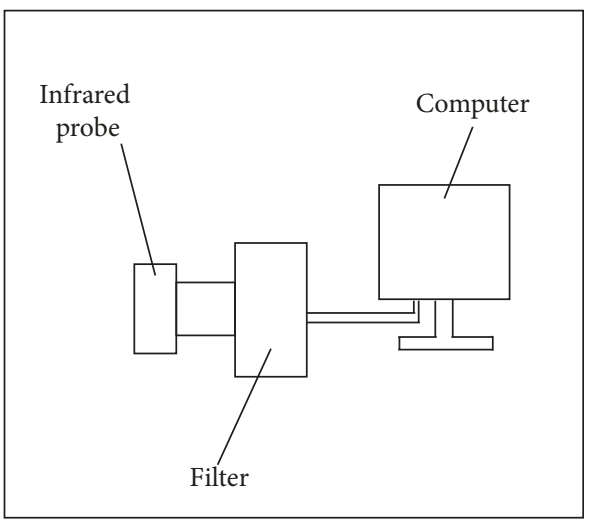

(b)

Figure 2: Combined melting glass purification and cyclic superheating experimental equipment schematic.

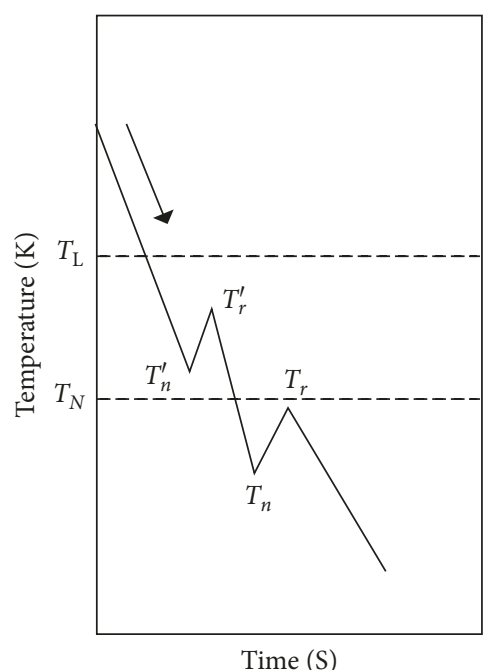

Figure 3: Cooling curves of the undercooled $\mathrm{Cu}-40 \mathrm{wt} . \% \mathrm{~Pb}$ alloy melt after quenching with copper mold.

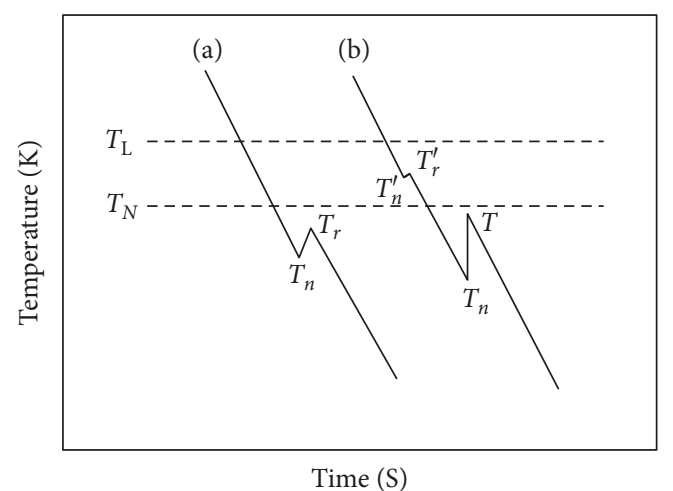

FIGURE 4: Schematic diagram of the cooling curve of the $\mathrm{Cu}-$ 40 wt.\% $\mathrm{Pb}-5$ wt.\% $\mathrm{Ni}$ alloy melt under different degrees of undercooling: (a) $\Delta T<143 \mathrm{~K}$ and (b) $\Delta T>143 \mathrm{~K}$.

low undercooling range of $40 \mathrm{~K} \leq \Delta T \leq 75 \mathrm{~K}$, according to the cooling curve of the alloy, liquid phase separation occurs inside the alloy melt. At this time, a few phase $L_{2}(\mathrm{~Pb})$ liquid phases distribute in the matrix $L_{1}(\mathrm{Cu})$ liquid phase. From the monotectic reaction $L_{1} \longrightarrow L_{2}+\alpha(\mathrm{Cu})$, it can be seen that the monotectic reaction first takes place in the droplets of the matrix phase. During the rapid solidification stage, because the monotectic cells always grow along the direction of exothermic heat, the phase dendrites formed by the reaction grow rapidly in the radial direction around them, so that the $L$ phase concentrating around the $L$ phase disperses and distributes among them. At the same time, the $L_{2}$ formed by the monotectic reaction distributes equally among the fibers $\alpha(\mathrm{Cu})$. The chrysanthemum-like monomorphic cell structure is formed between the two forms [14]. When the temperature is further cooled to $599 \mathrm{~K}$, eutectic reaction occurs in the $L_{2}$ phase. The $L_{2}(\mathrm{~Pb})$ phase is dispersed on the $S(\mathrm{Cu})$ substrate in a fibrous or granular form, as shown in Figure 5(a). With the deepening of undercooling, the number of monotectic cells in the alloy melt increases. In addition, higher undercooling increases the growth rate of monotectic cells, increases the probability of collision and adhesion between adjacent monotectic cells, enlarges the undercooling zone, and eventually leads to the formation of irregular monotectic cells in the alloy system, as shown in Figure 5(b). When the undercooling degree increases to $80 \mathrm{~K}$, the macrosegregation of $L_{2}$ phase appears obviously in the solidified structure of the alloy, and the undercooling zone increases further, as shown in Figure 5(c). As the undercooling deepens, the solidified structure of the alloy eventually delaminates, as shown in Figure 5(d) $[15,16]$.

Figure 6 shows the solidification structure of ternary $\mathrm{Cu}$ 40 wt.\% Pb-5 wt.\% Ni alloy at different undercooling. It can be seen from the graph that the solidification structure of the alloy becomes finer and finer with the increase of the undercooling degree when the melt undercooling degree is $\Delta T<143 \mathrm{~K}$. At that time, when the alloy melt has a degree of undercooling $\Delta T>143 \mathrm{~K}$, with the increase of the undercooling degree, the size of the second phase particles in the solidification structure of the alloy increases gradually until the appearance of the final stratification phenomenon. In this paper, the $\Delta T<143 \mathrm{~K}$ undercooled zone is called the homogenized undercooled zone of the alloy melt. In the homogenized undercooling zone, the second phase $\mathrm{S}(\mathrm{Pb})$ is 

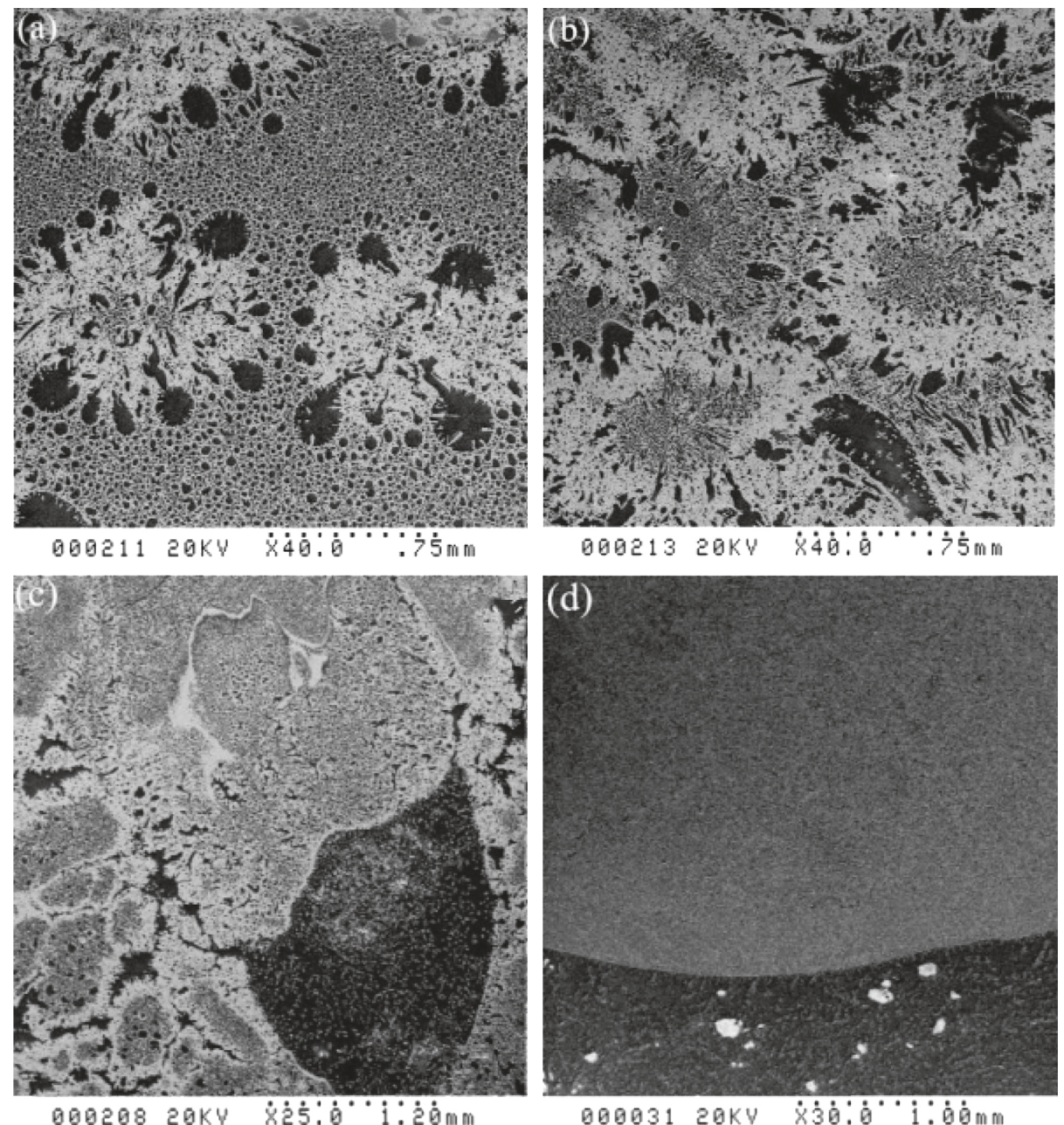

Figure 5: Microstructures of Cu- $40 \mathrm{wt} . \% \mathrm{~Pb}$ hypermonotectic alloy under different undercoolings: (a) $\Delta T=42 \mathrm{~K}$; (b) $\Delta T=65 \mathrm{~K}$; (c) $\Delta T=80 \mathrm{~K}$; and (d) $\Delta T=142 \mathrm{~K}$.

dispersed between the dendrites of $\alpha(\mathrm{Cu})$, and with the increase of undercooling degree, the dendrites of $\alpha(\mathrm{Cu})$ become finer and the distribution of the second phase $\mathrm{S}(\mathrm{Pb})$ becomes more uniform. When the undercooling of the alloy melt occurs at $\Delta T=143 \mathrm{~K}$, a small amount of Pb-rich phase flocculation appears in the solidified structure and disperses in the matrix, which means that the radius of $L_{2} \mathrm{~Pb}$-rich phase droplets increases continuously with the prolongation of separation time until its volume fraction approaches (or reaches) the critical value of homogenization. Before that, fast solidified dendrites of $\alpha(\mathrm{Cu})$ play a role in the continuous growth of the volume fraction of the second-phase Obvious Inhibition, as shown in Figure 6(e). When the undercooling degree is $\Delta T>143 \mathrm{~K}$, it can be judged from the cooling curve that the liquid phase separation occurs in the alloy melt. With the increase of the undercooling degree, the volume fraction of the second phase increases, which results in the increase in the size of the $\mathrm{Pb}$-rich phase flocs distributed between the dendrites of $\alpha(\mathrm{Cu})$ and the decrease in the uniformity of the distribution. When the undercooling degree is $\Delta T>160 \mathrm{~K}$, the second phase appears in the alloy structure under the action of Stokes motion Layered.
3.3. Effect of Third Component Ni on Interface Energy of Cu40 wt.\% Pb Alloy. According to Chadwick's [17] viewpoint of interfacial energy balance between solid phase $S$, liquid phase $L_{1}$, and liquid phase $L_{2}$ in the alloy melt, the formation mechanism of the monotectic alloy structure can be expressed as follows:

$$
\gamma_{\mathrm{SL}_{2}}>\gamma_{\mathrm{SL}_{1}}+\gamma_{\mathrm{L}_{1} \mathrm{~L}_{2}}
$$

$\gamma_{\mathrm{SL}_{2}}, \gamma_{\mathrm{SL}_{1}}$, and $\gamma_{\mathrm{L}_{1} \mathrm{~L}_{2}}$ in the formula represent the interfacial energy between solid $S$ and liquid $L_{2}$, solid $S$ and liquid $L_{1}$, and liquid $L_{1}$ and liquid $L_{2}$, respectively. Chadwick [17] believed that if the melt interface could satisfy equation (1) during the monotectic reaction, the liquid phase of $L_{2}$ would not wet the solid phase of $S$ through the monotectic reaction. Because $\gamma_{\mathrm{SL}_{2}}=310 \pm 10 \mathrm{mJm}^{-2}, \gamma_{\mathrm{SL}_{1}}=254 \pm 26 \mathrm{mJm}^{-2}$, and $\gamma_{\mathrm{L}_{1} \mathrm{~L}_{2}}=6 \pm 2 \mathrm{mJm}^{-2}$ in $\mathrm{Cu}-40 \mathrm{wt} . \% \mathrm{~Pb}$ monotectic alloy, the liquid phase of $L_{2}$ in $\mathrm{Cu}-40 \mathrm{wt} . \% \mathrm{~Pb}$ hypermonotectic alloy will not wet with solid phase $S$.

Although the interface of most monotectic alloys can satisfy formula (1), the corresponding size of $\gamma_{\mathrm{L}_{1} \mathrm{~L}_{2}}$ different alloys has a great influence on the solidification structure of 


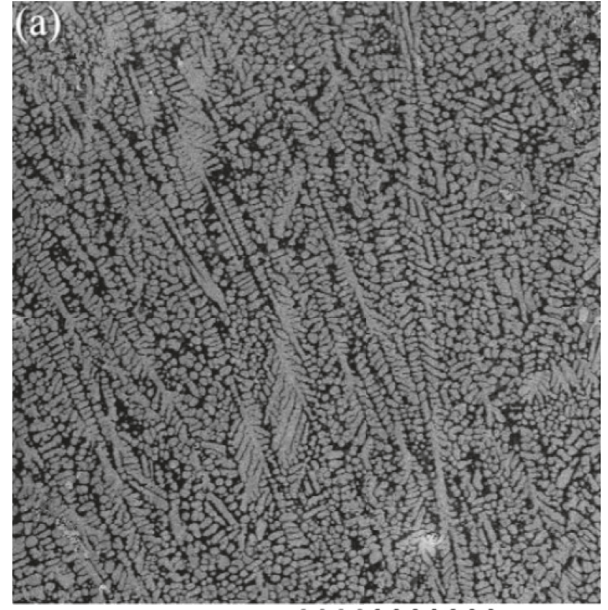

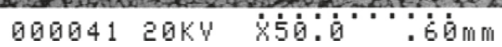

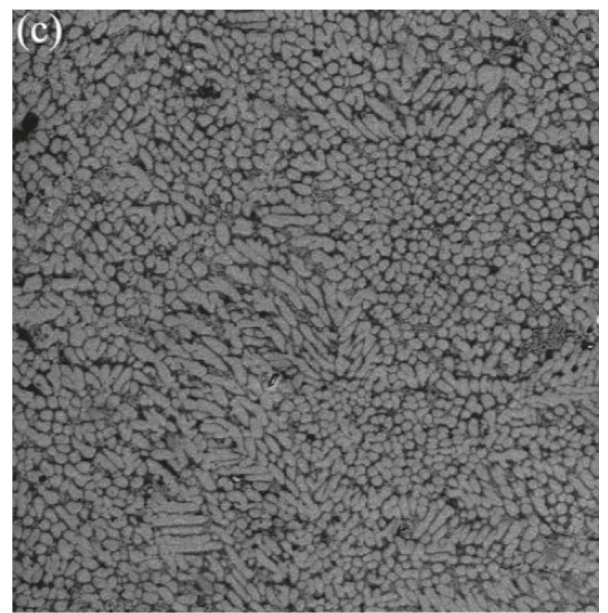

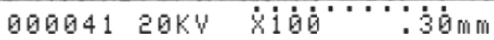

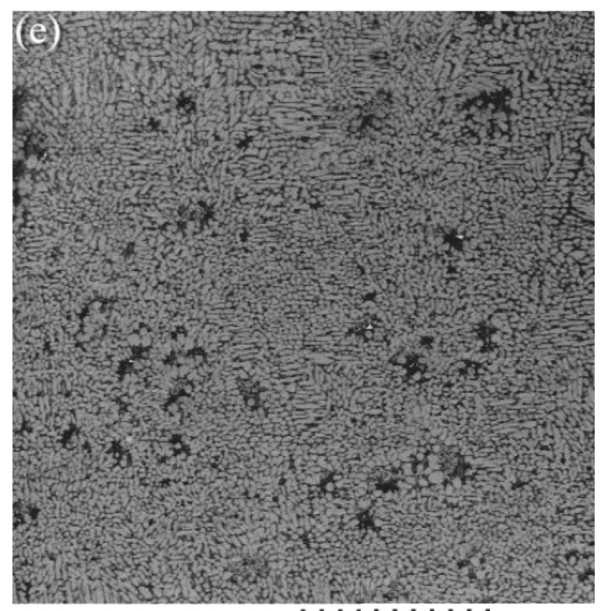

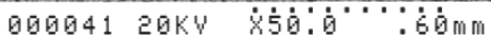

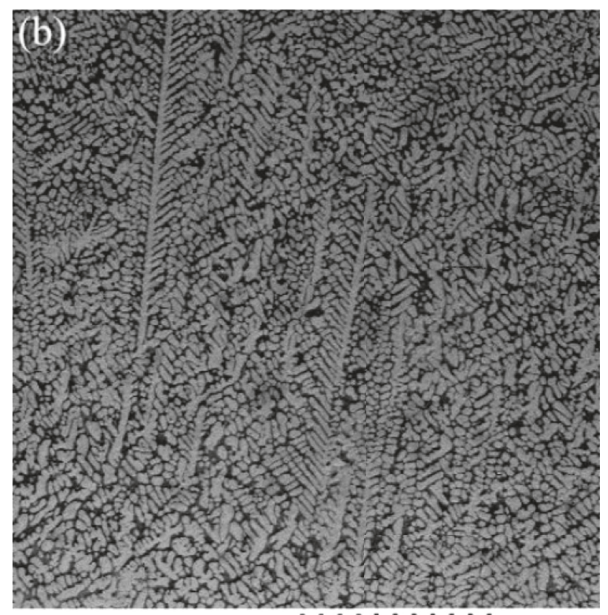

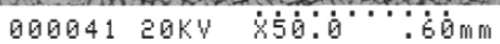

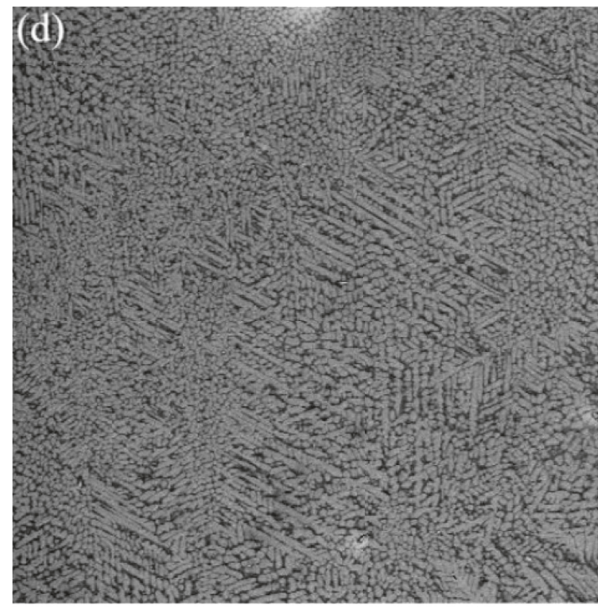

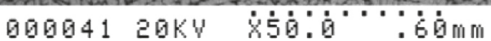

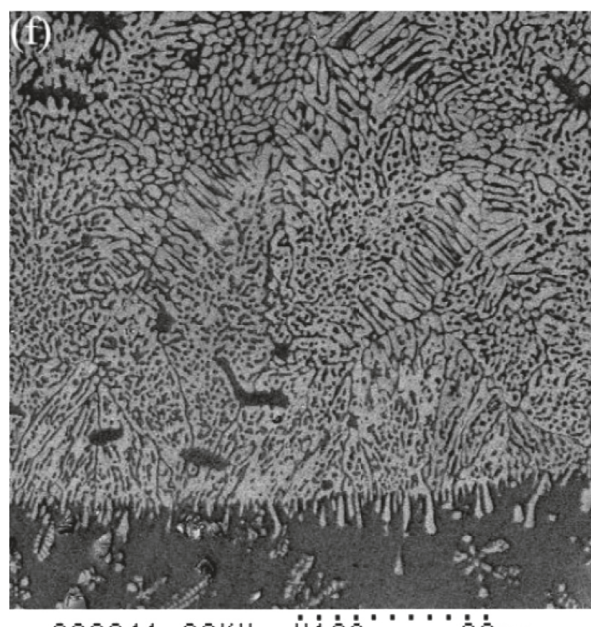

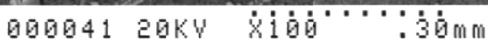

Figure 6: Microstructure of $\mathrm{Cu}-40 \mathrm{wt} . \% \mathrm{~Pb}-5 \mathrm{wt} \% \mathrm{Ni}$ with different undercoolings: (a) $\Delta T=58 \mathrm{~K}$; (b) $\Delta T=75 \mathrm{~K}$; (c) $\Delta T=98 \mathrm{~K}$; (d) $\Delta T=120 \mathrm{~K}$; (e) $\Delta T=143 \mathrm{~K}$; and (f) $\Delta T=160 \mathrm{~K}$.

the alloys. The larger the value of $\gamma_{\mathrm{L}_{1} \mathrm{~L}_{2}}$, the greater the barrier to form the second phase, the smaller the volume fraction of the separated second phase, and the more difficult it is for the second phase droplets to accumulate. The increase of the volume fraction of the second phase in the undercooled melt takes a longer time, which lays a foundation for improving the undercooling degree of homogenized solidification. The size of the immiscible zone in the liquid phase has a direct influence on $\gamma_{\mathrm{L}_{1} \mathrm{~L}_{2}} \cdot \gamma_{\mathrm{L}_{1} \mathrm{~L}_{2}}$ is shown in Table 1 .

The addition of $\mathrm{Al}$ in $\mathrm{Cu}-\mathrm{Pb}$ monotectic alloys enlarges the immiscible zone of the two phases and shifts the monotectic point to the direction of low concentration of 
TABLE 1: Monotectic point and miscibility gap in some monotectic alloys.

\begin{tabular}{lcc}
\hline Alloy & Monotectic point $(\mathrm{K})$ & Miscibility gap $(\mathrm{K})$ \\
\hline $\mathrm{Cu}-\mathrm{Pb}$ & 1228 & 36 \\
$\mathrm{Al}-\mathrm{Pb}$ & 931 & 769 \\
$\mathrm{Ni}-\mathrm{Pb}$ & 1651 & 210 \\
\hline
\end{tabular}

TABLE 2: $\gamma_{\mathrm{L}_{1} \mathrm{~L}_{2}}$ and miscibility gap in some monotectic alloys.

\begin{tabular}{lcc}
\hline Alloy & $\gamma_{\mathrm{L}_{1} \mathrm{~L}_{2}}\left(\mathrm{mJm}^{-2}\right)$ & Miscibility gap $(\mathrm{K})$ \\
\hline $\mathrm{Al}-\mathrm{Pb}$ & $145 \pm 30$ & 769 \\
$\mathrm{Al}-\mathrm{Bi}$ & 60 & 640 \\
$\mathrm{Al}-\mathrm{In}$ & $42 \pm 9$ & 306 \\
$\mathrm{Cu}-\mathrm{Pb}$ & $6 \pm 2$ & 36 \\
\hline
\end{tabular}

$\mathrm{Pb}$ [17]. Comparing the phase diagrams of $\mathrm{Al}-\mathrm{Pb}$ and $\mathrm{Ni}-$ $\mathrm{Pb}$, the immiscible temperature range (Table 2) shows that the immiscible temperature range of the two alloys is much higher than that of the $\mathrm{Cu}-\mathrm{Pb}$ alloy and the $\mathrm{Ni}-\mathrm{Pb}$ alloy has the largest solid solubility at the monotectic temperature point. Therefore, the addition of the third element $\mathrm{Ni}$ increases the $\gamma_{\mathrm{L}_{1} \mathrm{~L}_{2}}$ of $\mathrm{Cu}-\mathrm{Pb}$ alloy, weakens the separation of the second phase, and shifts the deviation point to the direction of low concentration of $\mathrm{Pb}$. Therefore, under small undercooling, $\alpha(\mathrm{Cu})$ is expressed as a reglow phenomenon in the cooling curve according to the singlephase solidification mode. With the increase of undercooling, the volume fraction of the separated second phase increases, and the coagulation effect is gradually reflected in the later stage. The cooling curve is reflected in the secondary re-glow, which leads to the deposition of the second phase $[15,18,19]$.

In theory, according to the expression of excess free energy of the ternary free system proposed by L. Ratke [18],

$$
G^{\mathrm{E}}=X_{\mathrm{A}} X_{\mathrm{B}} \Omega_{\mathrm{AB}}+X_{\mathrm{B}} X_{\mathrm{C}} \Omega_{\mathrm{BC}}+X_{\mathrm{C}} X_{\mathrm{A}} \Omega_{\mathrm{CA}} .
$$

In the formula, $\Omega_{\mathrm{AB}}=N_{0} Z \omega_{\mathrm{AB}}, N_{0}$ is the Avogadro constant, $Z$ is coordination number, $\omega_{\mathrm{AB}}$ is interaction coefficient between $\mathrm{A}$ and $\mathrm{B}$ atoms, $\omega_{\mathrm{AB}}=u_{\mathrm{AB}}-1 / 2$ $\left(u_{\mathrm{AA}}+u_{\mathrm{BB}}\right)$, and $u_{\mathrm{AB}}, u_{\mathrm{AA}}$, and $u_{\mathrm{BB}}$ represent affinity energy between $\mathrm{AB}, \mathrm{AA}$, and $\mathrm{BB}$ atoms, respectively. When the interaction coefficient $\omega_{\mathrm{AC}}$ and $\omega_{\mathrm{BC}}$ of the third component $\mathrm{Ni}$ and the $\mathrm{Cu}-\mathrm{Pb}$ alloy or the second phase are negative, that is, $u_{\mathrm{AC}}<1 / 2\left(u_{\mathrm{AA}}+u_{\mathrm{CC}}\right)$ and $u_{\mathrm{BC}}<1 / 2\left(u_{\mathrm{BB}}+u_{\mathrm{CC}}\right)$, both $\Omega_{\mathrm{BC}}$ and $\Omega_{\mathrm{AC}}$ are negative. Combined with formula (2), the free energy of the ternary $\mathrm{Cu}-\mathrm{Pb}-\mathrm{Ni}$ alloy system decreases. The change in the free energy of the system will inevitably have a certain degree of influence on the shape of the liquid phase immiscible region of the monocrystalline alloy system. Therefore, it can be seen from Figure 5 that the addition of the third component $\mathrm{Ni}$ leads to an increase in the critical subcooling of the liquid phase separation of the alloy system in the alloy phase diagram, thereby suppressing the growth of the second phase droplets in the alloy melt. Based on the above analysis, the solidification structure of the alloy melt was refined by adding the third element $\mathrm{Ni}$.

\section{Conclusion}

(i) The addition of the third element $\mathrm{Ni}$ increases the amount of $\mathrm{Cu}-40 \mathrm{wt} . \% \mathrm{~Pb}$ monotectic alloy and the immiscible zone, which leads to the weakening of liquid phase separation. The solidification structure is solidified by single-phase alloy in the range of $T=58 \mathrm{~K} \sim 143 \mathrm{~K}$. With the increase of undercooling, the transition from coarse dendrite to the first kind of granular and fine dendrite occurs.

(ii) The addition of the third component $\mathrm{Ni}$ changes the interface energy of $\mathrm{Cu}-40 \mathrm{wt} . \% \mathrm{~Pb}$ monotectic alloy, which can weaken the liquid phase separation, but cannot completely inhibit it.

(iii) Compared with $\mathrm{Cu}-40 \mathrm{wt} . \% \mathrm{~Pb}$ monotectic alloy, the addition of the third element $\mathrm{Ni}$ decreases the free energy of the alloy system, increases the critical undercooling degree of liquid phase separation, and decreases the volume fraction of $L_{2}$ phase separation in the immiscible zone.

\section{Data Availability}

The data used to support the findings of this study are available from the corresponding author upon request.

\section{Conflicts of Interest}

The authors declare that there are no conflicts of interest regarding the publication of this paper.

\section{Acknowledgments}

This work was supported by the National Natural Science Foundation of China (51561001, 51574171, and 51641406), the Natural Science Foundation of Shanxi Province of China (no. 201601D011012), Key Project of Shanxi Key Research and Development Program "Development of Ultra High Strength and Composite Wide and Heavy Plate Large Rolling Equipment"(201703D111003), Shanxi Province Science and Technology Major Project "Research on High Temperature, Corrosion and Wear Resistant Metal Composite Plate/Tube Material Technology" (MC2016-01) and NSFC-Shanxi Coal-Based Low-Carbon Joint Fund Support Project "Research on the Evolution and Performance of Key Materials in Ultra-Supercritical Boilers under Preparation and Service Conditions"(U610256), and Shanxi Province Science and Technology Major Project (20181102016).

\section{References}

[1] M. Shevchenko, S. Nicol, P. C. Hayes et al., "Experimental liquidus studies of the $\mathrm{Pb}-\mathrm{Cu}-\mathrm{Si}$-O system in equilibrium with metallic $\mathrm{Pb}-\mathrm{Cu}$ alloys," Metallurgical and Materials Transactions B, vol. 49, no. 4, pp. 1690-1698, 2018.

[2] H. Yokota, D. Yoshitome, H. Kobayashi et al., "Pb-free copper-alloy sliding material: EP,” US 7678173 B2, 2010. 
[3] V. E. Buchanan, P. A. Molian, T. S. Sudarshan, and A. Akers, "Frictional behavior of non-equilibrium $\mathrm{Cu}-\mathrm{Pb}$ alloys," Wear, vol. 146, no. 2, pp. 241-256, 1991.

[4] A. Munitz, A. Venkert, P. Landau, M. J. Kaufman, and R. Abbaschian, "Microstructure and phase selection in supercooled copper alloys exhibiting metastable liquid miscibility gaps," Journal of Materials Science, vol. 47, no. 23, pp. 7955-7970, 2012.

[5] H. Xie, J. Sun, G. C. Yang, Y. Z. Chen, and Z. L. Lu, "Liquid phase separation and its thermodynamic description in undercooled $\mathrm{Ni}-\mathrm{Pb}$ hypermonotectic melts," Materials Science and Engineering: A, vol. 457, no. 1-2, pp. 33-37, 2007.

[6] X. W. Zuo, E. G. Wang, H. Han et al., "Microstructures and magnetic properties of $\mathrm{Fe}-49 \% \mathrm{Sn}$ monotectic alloys solidified under a high magnetic field," Acta Metallurgica Sinica, vol. 44, no. 10, 2008.

[7] H. W. Zhang and A. P. Xian, "Study of Al-Bi immiscible alloy controlcast technique," Acta Metallurgica Sinica, vol. 35, no. 11, pp. 1187-1190, 1999.

[8] J. F. Xu, F. P. Dai, and B. B. Wei, "Phase separation of $\mathrm{Cu}-\mathrm{Pb}$ monotectic alloy during rapid solidification," Acta Physica Sinica, vol. 58, no. 7, pp. 3996-4003, 2007.

[9] Y. Niu, S. Y. Wang, and F. Gesmundo, "High-temperature scaling of $\mathrm{Cu}-\mathrm{Al}$ and $\mathrm{Cu}-\mathrm{Cr}-\mathrm{Al}$ alloys: an example of a nonclassical third-element effect," Oxidation of Metals, vol. 65, no. 5-6, pp. 285-306, 2006.

[10] S. Kang, M. Cho, D. Shih et al., "Controlling the interfacial reactions in $\mathrm{Pb}$-free interconnections by adding minor alloying elements to Sn-rich solders," in Proceedings of the Electronic Components \& Technology Conference, IEEE, Orlando, FL, USA, May 2008.

[11] S. Zhao, J. Li, L. Liu, and Y. Zhao, "Solidification of undercooled Ag-Cu eutectic alloy with the Sb addition," Journal of Alloys and Compounds, vol. 478, no. 1-2, pp. 252-256, 2009.

[12] B. J. Kim, K. I. Moon, and K. S. Lee, "The effect of the thirdelement addition on the fatigue properties of mechanically alloyed Al-Ti alloys," Journal of Alloys and Compounds, vol. 292, no. 1-2, pp. 174-180, 1999.

[13] W. X. Hao, G. C. Yang, H. Xie et al., "Rapid solidification behavior and microstrcture of high undercooled $\mathrm{Cu}-\mathrm{Pb}$ monotectic alloy melts," Chinese Journal of Materials Research, vol. 18, no. 4, pp. 357-364, 2004.

[14] B. Derby and J. J. Favier, "A criterion for the determination of monotectic structure," Acta Metallurgica, vol. 31, no. 7, pp. 1123-1130, 1983.

[15] G.-C. Yang, H. Xie, W.-X. Hao, Z.-M. Zhang, and X.-F. Guo, "Liquid-liquid phase separation in highly undercooled $\mathrm{Ni}-\mathrm{Pb}$ hypermonotectic alloys," Transactions of Nonferrous Metals Society of China, vol. 16, no. 2, pp. 290-293, 2006.

[16] S. Xiaosi, H. Weixin, G. Guihong, M. Teng, Li Yongtang et al., "Solidification microstructure evolution of undercooled $\mathrm{Cu}-$ 15 wt.\% Fe alloy melt," Advances in Materials Science and Engineering, vol. 2018, Article ID 6304518, 6 pages, 2018.

[17] A. Kamio, S. Kumai, and H. Tezuka, "Solidification structure of monotectic alloys," Materials Science \& Engineering A, vol. 146, no. 1-2, pp. 105-121, 1991.

[18] L. Ratke and S. Diefenbach, "Liquid immiscible alloys," Materials Science and Engineering: R: Reports, vol. 15, no. 7-8, pp. 263-347, 1995.

[19] B. C. Luo, H. P. Wang, and B. B. Wei, "Rapid solidification of ternary $\mathrm{Ni}-\mathrm{Pb}-\mathrm{Cu}$ monotectic alloy under free fall conditions," Chinese Journal of Nonferrous Metals, vol. 19, no. 2, pp. 279-285, 2009. 


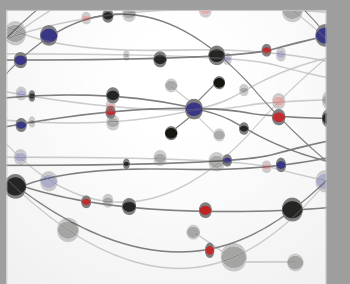

The Scientific World Journal
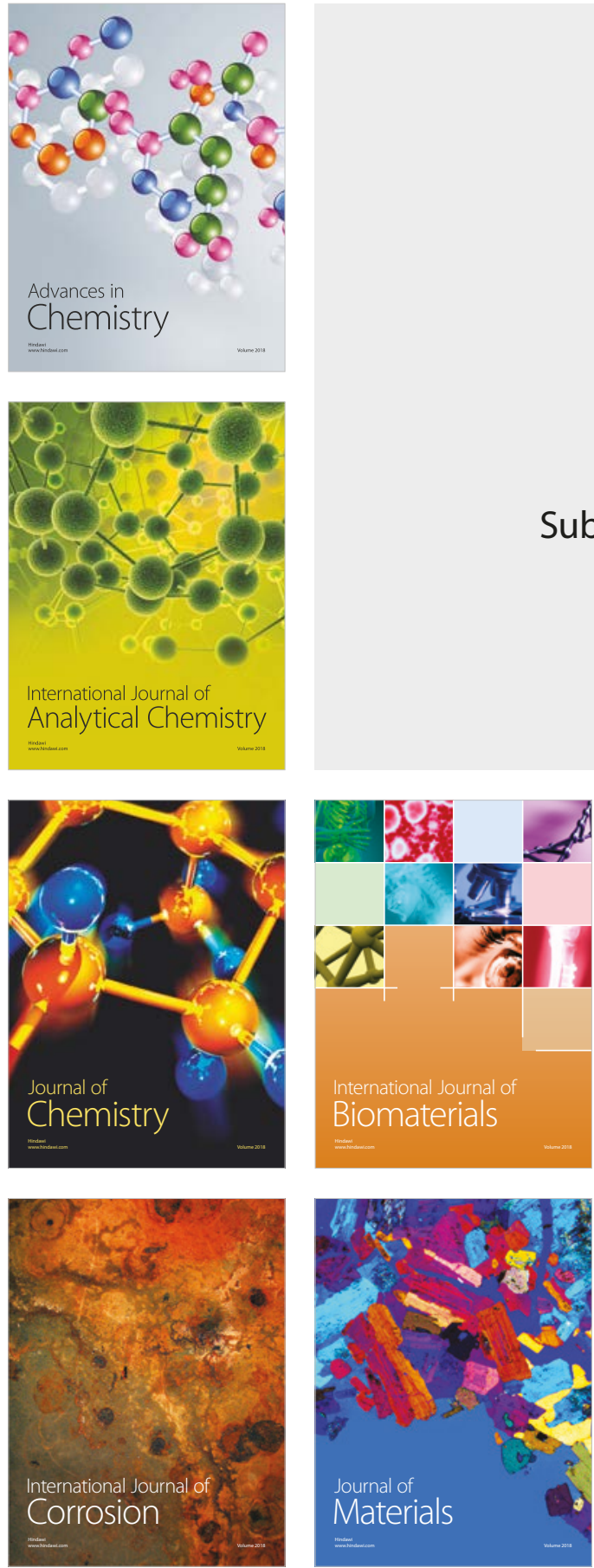

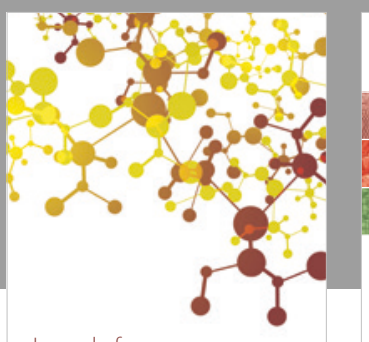

Journal of

Applied Chemistry
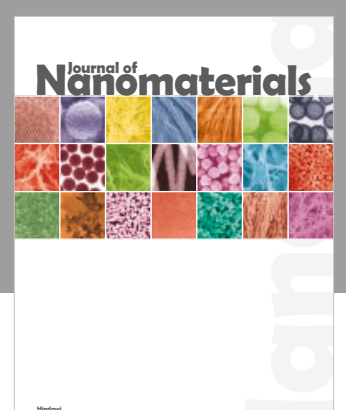

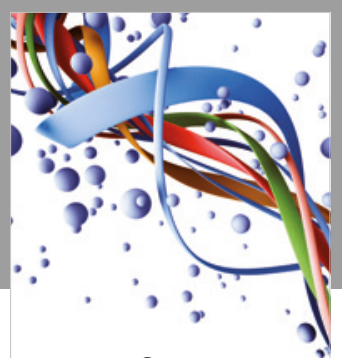

Scientifica

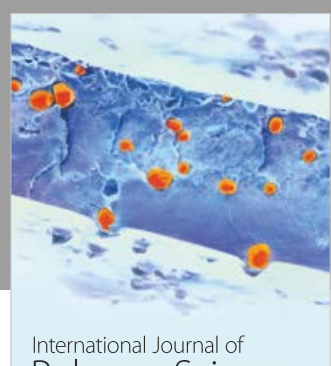

Polymer Science

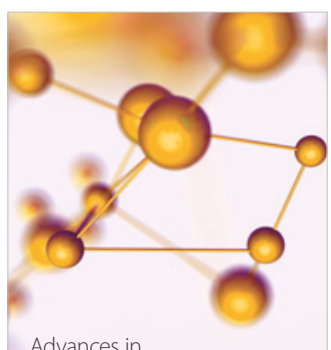

Physical Chemistry
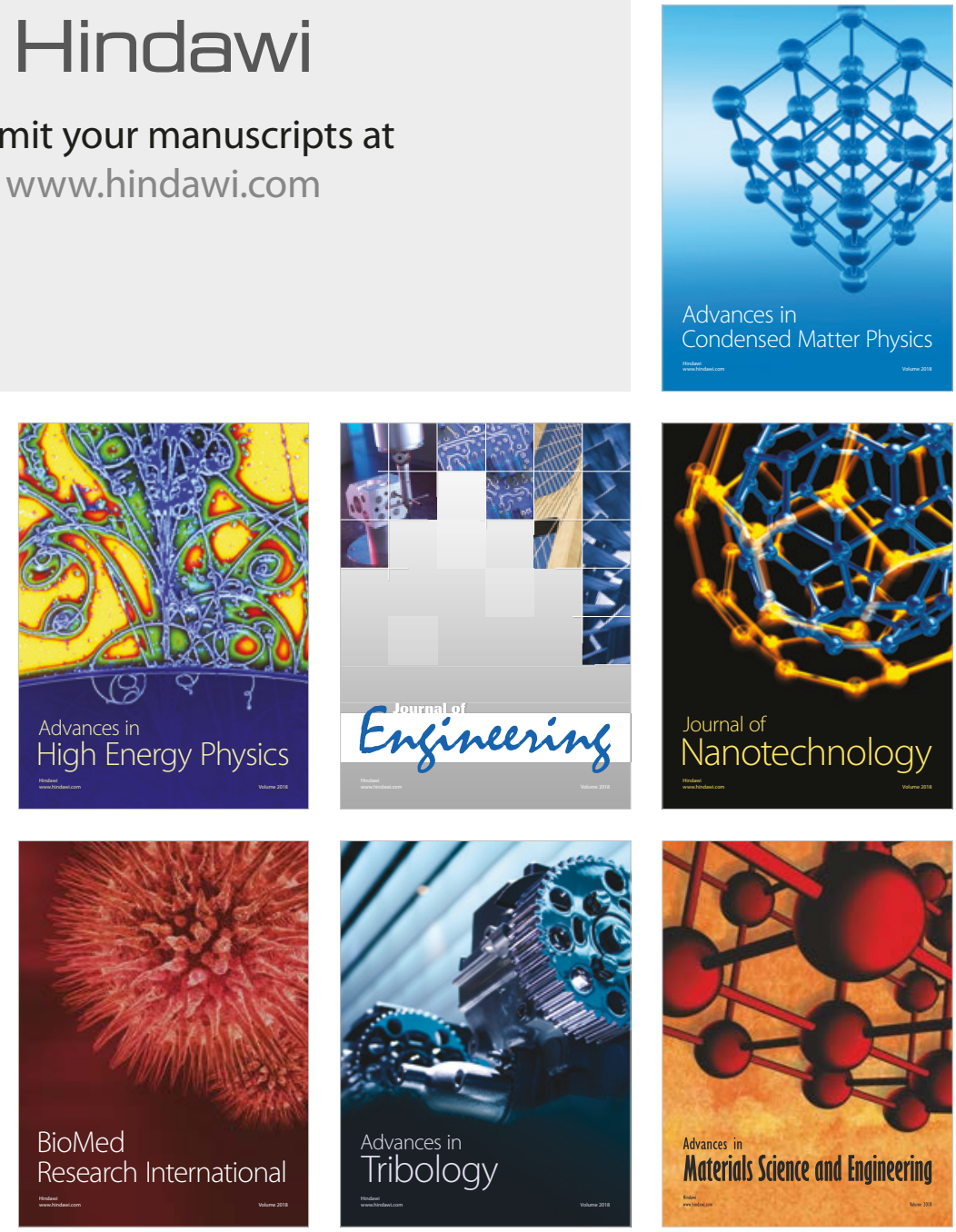